О. Ю. Бочкарьов, В. А. Голембо, Ю. А. Крайкін Національний університет “Львівська політехніка”, кафедра електронних обчислювальних машин

\title{
БЕЗДРОТОВА МЕРЕЖА СЕНСОРНИХ ТА ВИКОНАВЧИХ ВУЗЛІВ У СКЛАДІ КІБЕРФІЗИЧНОЇ СИСТЕМИ
}

\author{
() Бочкарьов О. Ю., Голебмбо В. А., Крайкін Ю. А., 2017
}

Розглянуто проблему розроблення бездротової мережі сенсорних та виконавчих вузлів у складі кіберфізичної системи (КФС). Проаналізовано способи реалізації схеми бездротового зв'язку. Запропоновано структуру та алгоритми роботи мережі. Наведено результати реалізації сенсорних та виконавчих вузлів мережі.

Ключові слова: бездротова мережа сенсорних та виконавчих вузлів, кіберфізична система.

A. Botchkaryov, V. Golembo, Yu. Kraikin Lviv Polytechnic National University, Computer Engineering Department

\section{WIRELESS SENSOR-ACTUATOR NETWORK AS A PART OF THE CYBER-PHYSICAL SYSTEM}

(C) Botchkaryov A., Golembo V., Kraikin Yu., 2017

The problem of developing wireless sensor-actuator network as a part of the cyber-physical system is considered. The ways of implementation of the wireless connections' scheme are analyzed. The network structure and algorithms of its operation are proposed. The results of implementation of the sensor and actuator nodes are considered.

Key words: wireless sensor-actuator network, cyber-physical system.

\section{Вступ}

Одним з основних компонентів сучасних КФС [1-5] є бездротові мережі сенсорних [6] та виконавчих вузлів (МСВВ). Кількість різних варіантів практичного застосування бездротових MCBB та їх масштаби постійно зростають. Серед найвідоміших сфер застосування бездротових МСВВ можна виділити технології домашньої автоматизації (home automation, smart house), технології "розумного міста" (smart city), автономні сільськогосподарські системи (autonomous agricultural systems), автономні транспортні системи (autonomous transportation systems), автономні системи наукових досліджень тощо. Також треба зазначити, що бездротові МСВВ є одним 3 найперспективніших напрямів дослідження, розроблення та впровадження інтелектуальних технологій збирання даних [7], зокрема інтелектуальних технологій збирання даних на основі принципів самоорганізації та концепції структурної адаптації [8-11].

У роботі розглянуто проблему розроблення бездротової мережі сенсорних та виконавчих вузлів у складі кіберфізичної системи, проаналізовано різні варіанти компонування вузлів бездротової МCBВ, різні варіанти технологій бездротового зв'язку для ії побудови та способи 
реалізації схеми бездротового зв'язку. Також у роботі запропоновано структуру та алгоритми роботи бездротової МCBB на основі технології бездротового зв'язку Wi-Fi, наведено результати реалізації сенсорних та виконавчих вузлів мережі. Базова функціональність розробленої МСВВ передбачає: 1) можливість збирання вимірювальної інформації з давачів фізичних величин та виконання команд виконавчими пристроями в автономному режимі; 2) можливість віддаленого перегляду показів давачів та введення команд для виконавчих пристроїв з консолей управління.

\section{Стан проблеми}

Серед технологій (стандартів) бездротового зв'язку, які можна використати для побудови MCBB, розглянемо такі поширені технології бездротового зв'язку на коротких відстанях: Bluetooth, ZigBee тa Wi-Fi. Порівняння цих технологій та інших найпоширеніших технологій бездротового зв'язку наведено в табл. 1. Для кожної з цих технологій існує велике різноманіття радіочастотних модулів різного рівня готовності, що відрізняються один від одного технічними параметрами i характеристиками. Відтак особливо актуальною $є$ проблема розроблення методології вибору конкретної технології бездротового зв'язку і конкретної елементної бази (зокрема модулів бездротового зв'язку) для побудови МСВВ.

Таблиия 1

Основні параметри технологій бездротового зв'язку

\begin{tabular}{|c|c|c|c|c|c|c|}
\hline & ZigBee & Bluetooth & Wi-Fi & 434/868 МГц & GSM/GPRS/EDGE & $3 G$ \\
\hline $\begin{array}{c}\text { Діапазон } \\
\text { частот, МГц }\end{array}$ & $2400-2483$ & $2400-2483$ & $2400-2483$ & $434 / 868$ & $900 / 1800$ & $\begin{array}{l}1885-2025 ; \\
2110-2200\end{array}$ \\
\hline $\begin{array}{c}\text { Швидкість } \\
\text { передавання } \\
\text { даних, кбіт/с }\end{array}$ & 250 & 721 & $11000 / 54000$ & 500 & $14,4 / 171 / 473$ & $\begin{array}{c}144 / 384 / \\
2048\end{array}$ \\
\hline Відстань, м & 200 & $\begin{array}{c}\text { Клас } 1-100 ; \\
\text { клас } 2-10 ; \\
\text { клас } 3-1\end{array}$ & 100 & 1000 & зона покриття & $\begin{array}{c}\text { зона } \\
\text { покриття }\end{array}$ \\
\hline $\begin{array}{c}\text { Струм } \\
\text { споживання, } \\
\text { мА }\end{array}$ & 30 & 70 & 450 & 30 & $350 / 3500$ & $350 / 3500$ \\
\hline Топологія & $\begin{array}{l}\text { “точка- } \\
\text { точка”, } \\
\text { “зірка”, } \\
\text { мережа }\end{array}$ & $\begin{array}{l}\text { “точка- } \\
\text { точка”, } \\
\text { “зірка”, } \\
\text { мережа }\end{array}$ & $\begin{array}{l}\text { “точка- } \\
\text { точка", } \\
\text { “зірка", }\end{array}$ & $\begin{array}{l}\text { “точка- } \\
\text { точка”, } \\
\text { “зірка”, } \\
\text { мережа }\end{array}$ & $\begin{array}{c}\text { мобільний } \\
\text { зв’ язок }\end{array}$ & $\begin{array}{c}\text { мобільний } \\
\text { зв' язок }\end{array}$ \\
\hline
\end{tabular}

\section{Постановка задачі}

Розглянути проблему розроблення бездротової мережі сенсорних та виконавчих вузлів у складі кіберфізичної системи, проаналізувати різні варіанти компонування вузлів бездротової MCBВ, різні варіанти технологій бездротового зв'язку для ії побудови та способи реалізації схеми бездротового зв'язку. Розробити структуру та алгоритми роботи бездротової МСВВ. Реалізувати сенсорні та виконавчі вузли мережі.

\section{Розв'язання задачі}

1. Узагальнена схема бездротової МСВВ. Розглянемо узагальнену схему бездротової МСВВ (рис. 1), у яку входять: S (sensor node) - сенсорний вузол (збирає вимірювальну інформацію 3 давачів фізичних величин); A (actuator) - виконавчий вузол (формує та виконує команди управління виконавчими системами); CU (control unit) - блок управління (отримує вимірювальну інформацію від сенсорних вузлів, виконує іï аналіз та формує команди управління); X (PC, Smartphone) пристрій доступу до блока управління (консоль управління). 
На основі цієї схеми можна визначити чотири основні варіанти компонування вузлів бездротової МСВВ (рис. 2), тобто варіанти розміщення вузлів у межах однієї компоненти (пристрою) $\mathrm{MCBB}$, зокрема: 1) $\mathrm{K}_{1}=[\mathrm{S}, \mathrm{CU}, \mathrm{A}]-[\mathrm{X}]-$ сенсорний вузол, виконавчий вузол та вузол управління об' єднані в один пристрій, внаслідок чого в цьому варіанті $є$ лише одна лінія зв' язку між пристроєм [S, CU, A] та консоллю управління [X]; 2) $\mathrm{K}_{2}=[\mathrm{S}]-[\mathrm{CU}, \mathrm{A}]-[\mathrm{X}]-$ виконавчий вузол та вузол

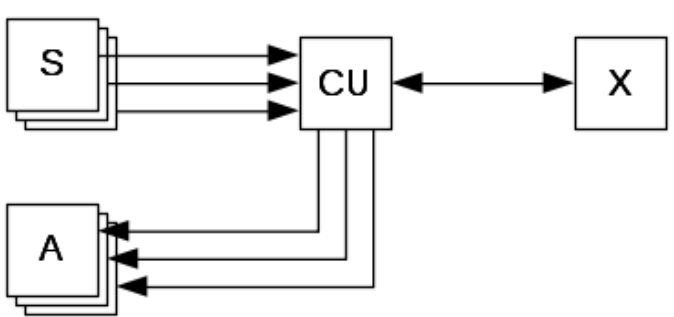

Рис. 1. Узагальнена схема бездротової $М С B В$ управління об' єднані в один пристрій, сенсорний вузол та консоль управління - це окремі пристрої, внаслідок чого цей варіант передбачає наявність двох ліній зв'язку; 3) $\mathrm{K}_{3}=[\mathrm{A}]-[\mathrm{S}, \mathrm{CU}]-[\mathrm{X}]-$ сенсорний вузол та вузол управління об'єднані в один пристрій, виконавчий вузол та консоль управління - це окремі пристрої; 4) $\mathrm{K}_{4}=[\mathrm{S}]-[\mathrm{A}]-[\mathrm{CU}]-[\mathrm{X}]$ - всі основні вузли реалізовано у вигляді окремих пристроїв, внаслідок чого цей варіант передбачає наявність трьох ліній зв'язку.

Отже, за вибором та реалізацією тих чи інших варіантів компонування вузлів можна поділити всі МСВВ на: 1) однорідні, в яких реалізовано лише один варіант компонування вузлів, та 2) неоднорідні, в яких одночасно реалізовано декілька варіантів компонування. Аналіз та проектування однорідних МСВВ видається простішим завданням, ніж аналіз та проектування неоднорідних МСВВ. У найскладнішому випадку в схемі бездротової МСВВ реалізуються всі основні варіанти компонування вузлів $\left(\mathrm{K}_{1}, \mathrm{~K}_{2}, \mathrm{~K}_{3}, \mathrm{~K}_{4}\right)$.
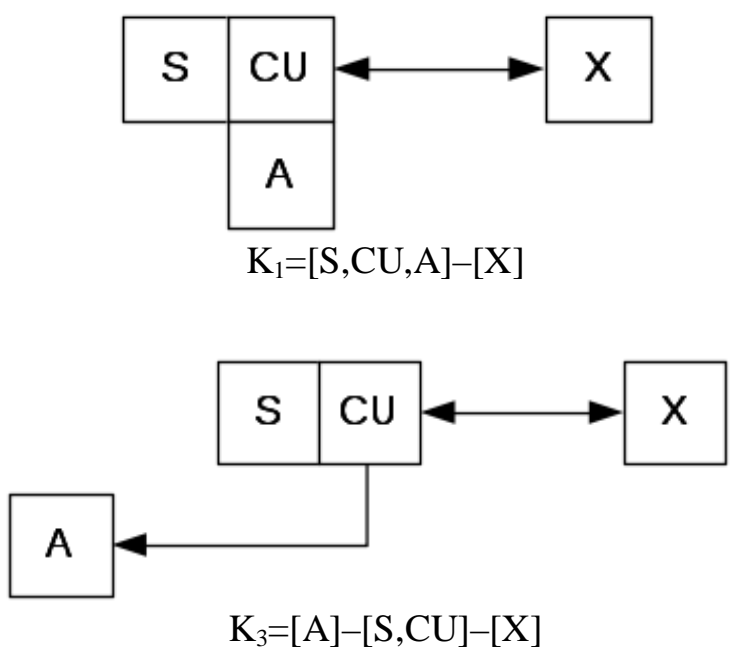
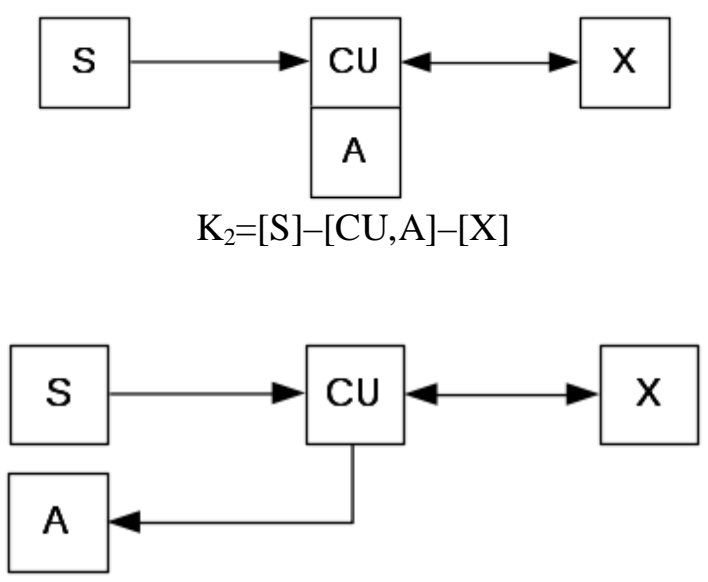

$\mathrm{K}_{4}=[\mathrm{S}]-[\mathrm{A}]-[\mathrm{CU}]-[\mathrm{X}]$

Рис. 2. Варіанти компонування вузлів бездротової $М С B В$

На основі того чи іншого варіанта компонування вузлів можна розглядати різні варіанти реалізації схем зв'язку між компонентами МСВВ. Наприклад, для варіанта компонування $\mathrm{K}_{4}$ та множини доступних способів реалізації лінії зв'язку $\mathrm{C}=\left\{\mathrm{c}_{1}, \mathrm{c}_{2}, \mathrm{c}_{3}\right\}$, де $\mathrm{c}_{1}-$ дротовий зв'язок, $\mathrm{c}_{2}-$ зв'язок на основі технології Bluetooth (BT), $c_{3}$ - бездротовий зв' язок на основі простих радіомодулів (RI), можна визначити дев'ять основних варіантів реалізації схем зв'язку між компонентами МСВВ (рис. 3), зокрема: 1) дротові зв'язки між усіма компонентами; 2) зв'язок між сенсорним вузлом та блоком управління через інтерфейс Bluetooth, інші зв'язки дротові; 3) зв'язок між вузлом управління та консоллю управління через інтерфейс Bluetooth, інші зв'язки дротові; 4) зв'язок між сенсорним вузлом, вузлом управління та виконавчим вузлом через інтерфейс Bluetooth, інші зв'язки дротові; 5) між усіма компонентами зв'язок через інтерфейс Bluetooth; 6) зв'язок між сенсорним вузлом та вузлом управління через радіоінтерфейс, інші зв'язки дротові; 7) зв'язок між сенсорним вузлом та вузлом управління через радіоінтерфейс, між виконавчим вузлом та вузлом управління 
через інтерфейс Bluetooth, між консоллю управління та вузлом управління - дротовий зв'язок; 8) зв'язок між сенсорним вузлом та вузлом управління через радіоінтерфейс, інші зв'язки через iнтерфейс Bluetooth; 9) зв'язок між сенсорним вузлом та блоком управління через радіоінтерфейс, між вузлом управління та виконавчим вузлом через дротове з'єднання, між консоллю управління та вузлом управління через інтерфейс Bluetooth.

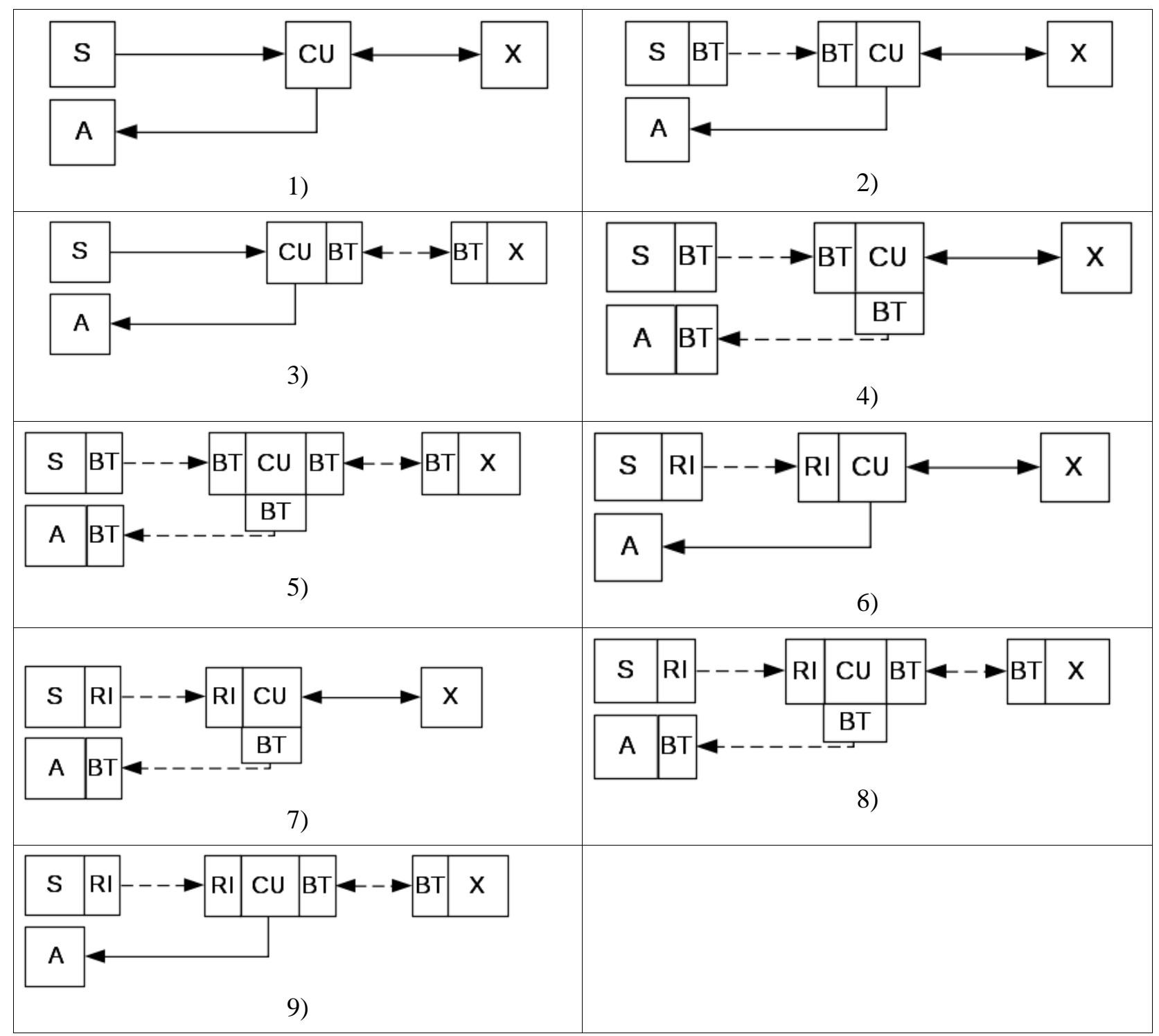

Рис. 3. Варіанти реалізаиії схеми зв'язків між компонентами МСВВ для варіанта компонування $K_{4}$

Проаналізувавши технології та модулі бездротового зв'язку (табл. 2), варіанти компонування вузлів бездротової МСВВ та варіанти реалізації схем зв'язку між ії компонентами, ми вибрали технологію Wi-Fi та відповідно модуль бездротового зв'язку ESP8266 для побудови однорідної MCBВ у варіанті компонування $\mathrm{K}_{4}$.

2. Структура та алгоритми роботи бездротової МСВВ. Базова функціональність МСВВ реалізується так (рис. 4). Вузол управління приймає вимірювальну інформацію від сенсорних вузлів через інтерфейс Wi-Fi за допомогою маршрутизатора (Wi-Fi router). 3 будь-якої консолі управління можна переглянути цю інформацію. У структурі також передбачено можливість автономної роботи виконавчих вузлів, які отримують на вхід результати аналізу вимірювальної інформації, що виконується на вузлах управління. Крім того, виконавчим вузлам можна або віддавати команди безпосередньо з консолі управління, або надсилати команди з вузлів управління в автономному 
режимі роботи. Зв'язок виконавчих вузлів 3 вузлами управління також здійснюється через інтерфейс Wi-Fi за допомогою маршрутизатора.

Відтак структура бездротової МСВВ складається з таких основних компонентів: сенсорні вузли, вузли управління, виконавчі вузли, консолі управління та середовище передавання даних (рис. 5). При цьому: 1) сенсорний вузол містить давачі фізичних величин (сенсори), Wi-Fi-модуль бездротового зв'язку (ESP8266) та літій-іонний акумулятор для забезпечення автономної роботи; 2) виконавчий вузол містить контролер (Arduino UNO) для керування виконавчими системами, Wi-Fi модуль бездротового зв'язку (ESP8266) та літій-іонний акумулятор; 3) середовище передавання даних реалізовано на основі одного або декількох маршрутизаторів мережі Wi-Fi 3 можливістю доступу до мережі Інтернет; 4) можливість віддаленого доступу до МСBВ з консолей управління реалізована на основі web-серверів, які виконуються на відповідних вузлах управління.

Таблиия 2

Характеристики модулів бездротового зв'язку

\begin{tabular}{|l|l|c|c|c|c|c|c|}
\hline № & Модуль & $\begin{array}{c}\text { Ціна, } \\
\text { грн }\end{array}$ & $\begin{array}{c}\text { Енергоспожи- } \\
\text { вання, мА }\end{array}$ & $\begin{array}{c}\text { Відстань, } \\
\text { м }\end{array}$ & $\begin{array}{c}\text { Типорозмір, } \\
\text { мм }\end{array}$ & $\begin{array}{c}\text { Пропускна } \\
\text { здатність, } \\
\text { Мбіт/с }\end{array}$ & Примітки \\
\hline & Bluetooth & & & & & & \\
\hline 1 & HC-03-06 & 150 & $30-40$ & 10 & $44 \times 16 \times 4$ & $2-3$ & $3,4-П, 5,6-К$ \\
\hline 2 & HC-07 & 200 & 20 & 10 & $44 \times 16 \times 4$ & $2-3$ & LowEnergy \\
\hline 3 & HC-08 & 200 & 20 & 80 & $44 \times 16 \times 4$ & 8 & LowEnergy \\
\hline 4 & HC-09 & 170 & 25 & 10 & $44 \times 16 \times 4$ & 8 & Заміна НC-06-07 \\
\hline & Radio & & & & & & \\
\hline 5 & HM-R433 & 170 & 5 & 200 & $30 \times 14 \times 7$ & 0.004 & 433 МГц \\
\hline 6 & NRF24L01 & 50 & 12.5 & 50 & $29 \times 16 \times 13$ & 2 & 2,4 ГГц \\
\hline & Wi-Fi & & & & & & \\
\hline 7 & ESP8266 & 120 & 15 & 20 & $11.5 \times 11.5 \times 2$ & 5 & 2.4 ГГц \\
\hline
\end{tabular}

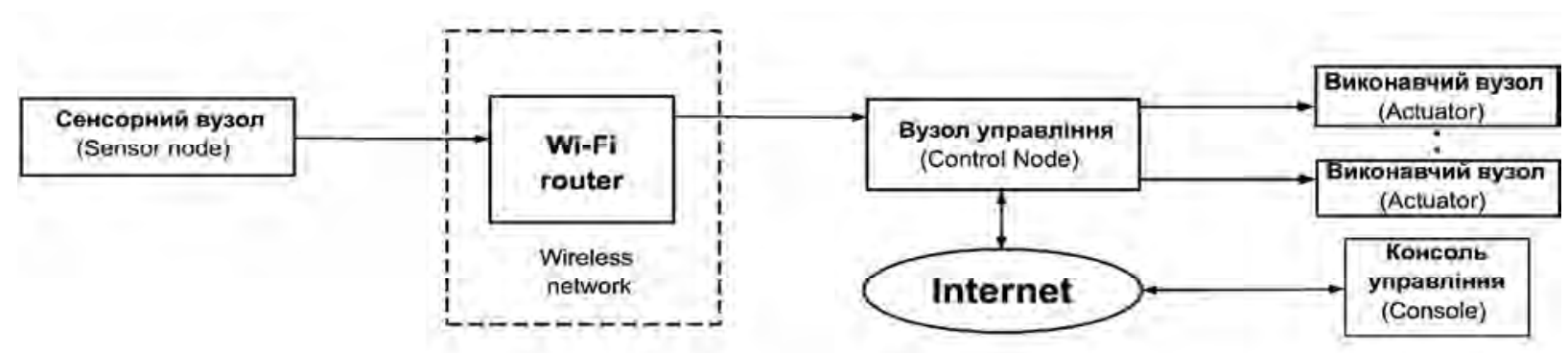

Рис. 4. Загальна структурна схема бездротової МСВВ

Алгоритм роботи сенсорного вузла (рис. 6, а) складається з таких кроків. Сенсорний вузол ініціалізує власний web-сервер та створює відповідну web-сторінку. Далі сенсорний вузол опитує “свої” давачі $\{\mathrm{D}$ (i) \}, зчитує вимірювальну інформацію та зберігає іiі. Коли отримано інформацію 3 усіх давачів, виконується необхідне перетворення форматів даних (дешифрація) та виведення інформації на раніше створену web-сторінку. Далі відбувається затримка та перехід на початок циклу.

Алгоритм роботи виконавчого вузла (рис. 6, б) складається з таких кроків. Виконавчий вузол ініціалізує власний web-сервер та створює відповідну web-сторінку. На цю сторінку виводяться органи керування (кнопки web-інтерфейсу), для здійснення команд управління (ввімкнення та вимкнення виконавчих систем). Далі виконується опитування web-сторінки на предмет змін стану органів керування. Якщо зміна відбулася, то виконується вмикання або вимикання відповідної виконавчої системи та збереження стану до надходження наступної команди. 


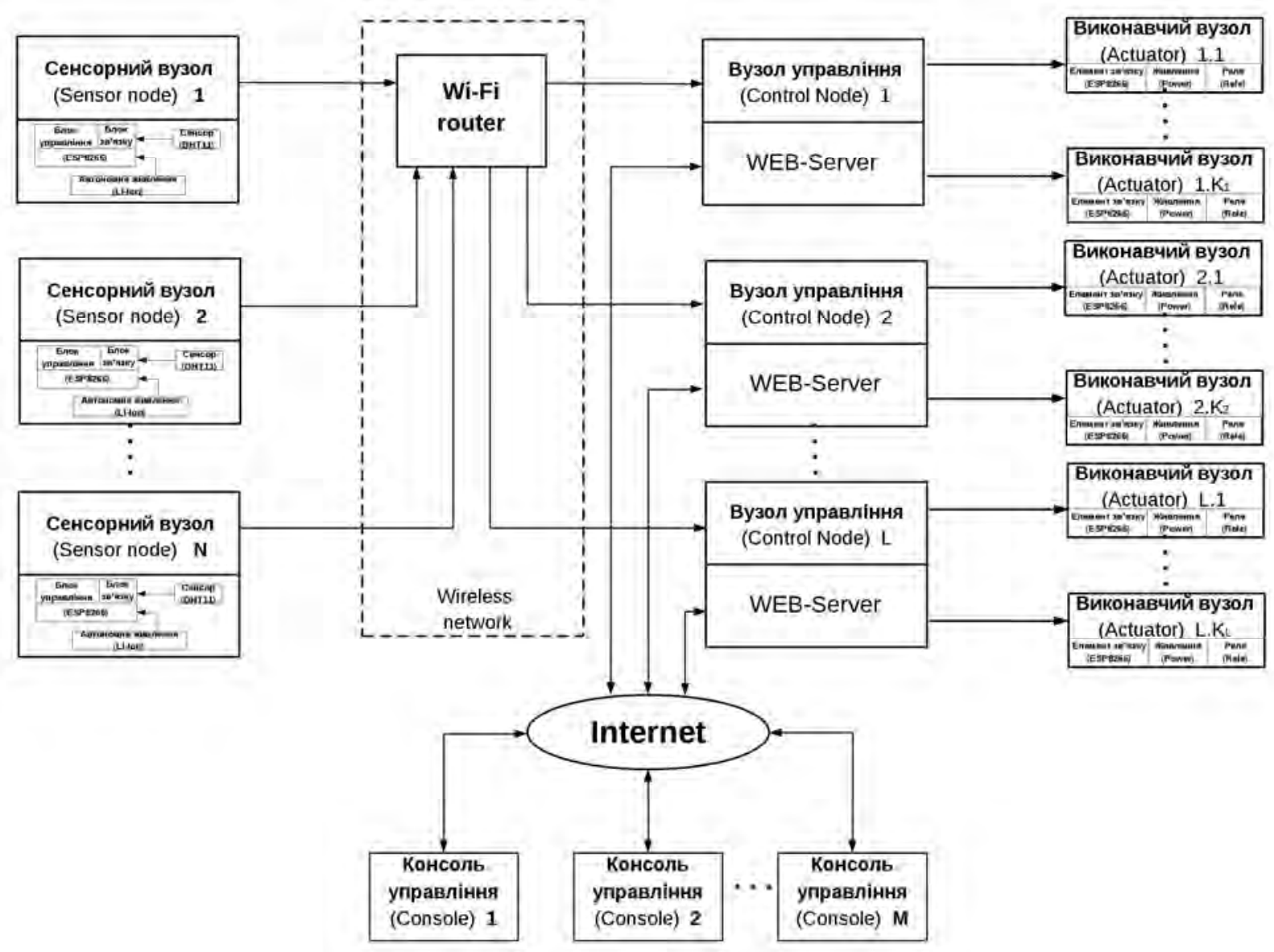

Рис. 5. Розгорнута структурна схема бездротової МСВВ

3. Реалізація сенсорного вузла бездротової МСВВ. Сенсорний вузол реалізовано за допомогою чотирьох функціональних вузлів (рис. 7): сенсорний модуль, вузол зв'язку, вузол живлення для модуля зв'язку, вузол живлення для сенсорного модуля. Сенсорний модуль реалізовано на основі давача вологості та температури DHT11. Вузол зв'язку реалізовано на основі Wi-Fi-модуля бездротового зв'язку ESP8266. Він використовується для зчитування даних із сенсорного модуля, їх декодування та подальшого передавання вузлу управління. Вузол живлення для модуля зв'язку виконує формування постійної напруги 3,3 В для модуля зв'язку, використовуючи стабілізатор LM317T. Також на вході та виході стабілізатора встановлено конденсатори для згладжування коливань (ємність від 60 нФ до 100 нФ). Вузол живлення для сенсорного модуля формує постійну напругу $5 \mathrm{~B}$, для чого використовується стабілізатор NCP1117S та конденсатори на його виході для згладжування коливань.

Конструкція прототипу сенсорного вузла складається з чотирьох комплектуючих (рис. 8) та корпуса з габаритними розмірами 80х60х30 мм (рис. 9), в якому зроблено отвори для вимикача $\mathrm{i}$ роз'єму Micro USB, що використовується для заряджання акумулятора. Основні характеристики реалізованого прототипу сенсорного вузла такі: 1) живлення - 3,7 B; 2) споживана потужність $82 \mathrm{мBт;} \mathrm{3)} \mathrm{час} \mathrm{автономної} \mathrm{роботи} \mathrm{-} 96$ год; 4) максимальна кількість давачів - 2 шт.; 5) ємність акумулятора - 2400 мА; 6) час повного заряджання $-2,5$ год; 7) габаритні розміри $-80 \times 60 \times 30$ мм.

4. Реалізація виконавчого вузла бездротової МСВВ. Виконавчий вузол реалізовано за допомогою чотирьох функціональних вузлів (рис. 10): мікроконтролер, вузол зв'язку, вузол живлення для модуля зв'язку, вузол живлення для мікроконтролера, вузол синхронізації, вузол скидання. Як мікроконтролер використано ATMEGA328-A на базі плати Arduino Uno. Мікроконтролер керує вузлом зв'язку та виконавчими системами (силовими пристроями) за 
допомогою реле. Вузол зв'язку реалізовано на основі Wi-Fi-модуля бездротового зв'язку ESP8266. Він використовується для передавання та приймання даних, зокрема для створення web-сервера та сторінки $з$ елементами контролю на ній, а також для контролю змін стану цих елементів. Вузол синхронізації призначений для формування тактових сигналів для мікроконтролера. Причому чим вища їх частота, тим швидше виконуються операції, і чим нижча їх частота, тим менше споживання струму. Для реалізації зовнішнього генератора використано кварц 3 частотою 32,768 кГц (під'єднаний до виводів XTAL1 i XTAL2 мікроконтролера). Вузол скидання формує сигнал скидання для початкової ініціалізації мікроконтролера (вузол скидання під'єднаний до виводу RST мікроконтролера).
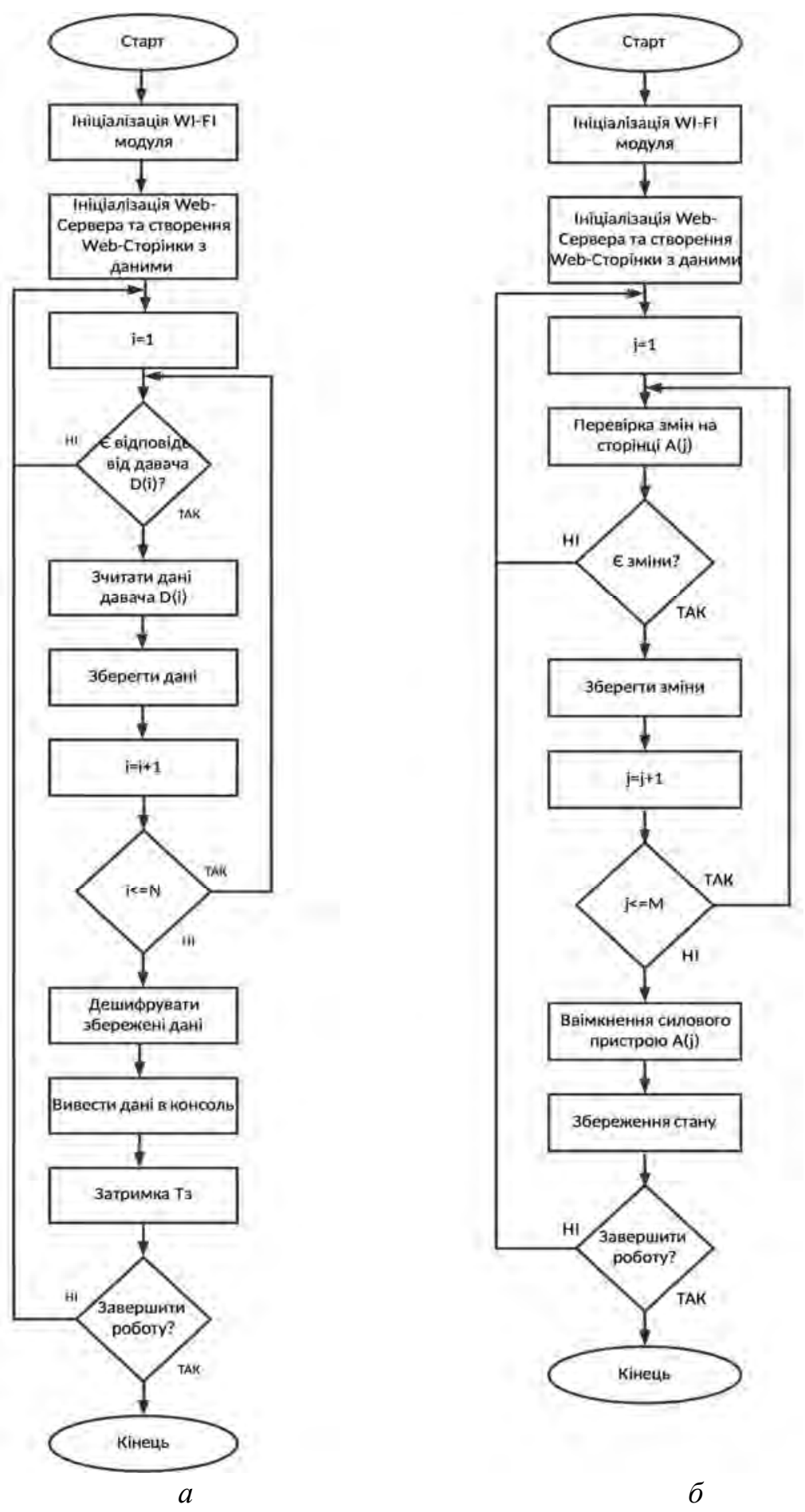

Рис. 6. Алгоритми роботи бездротової МСВВ 


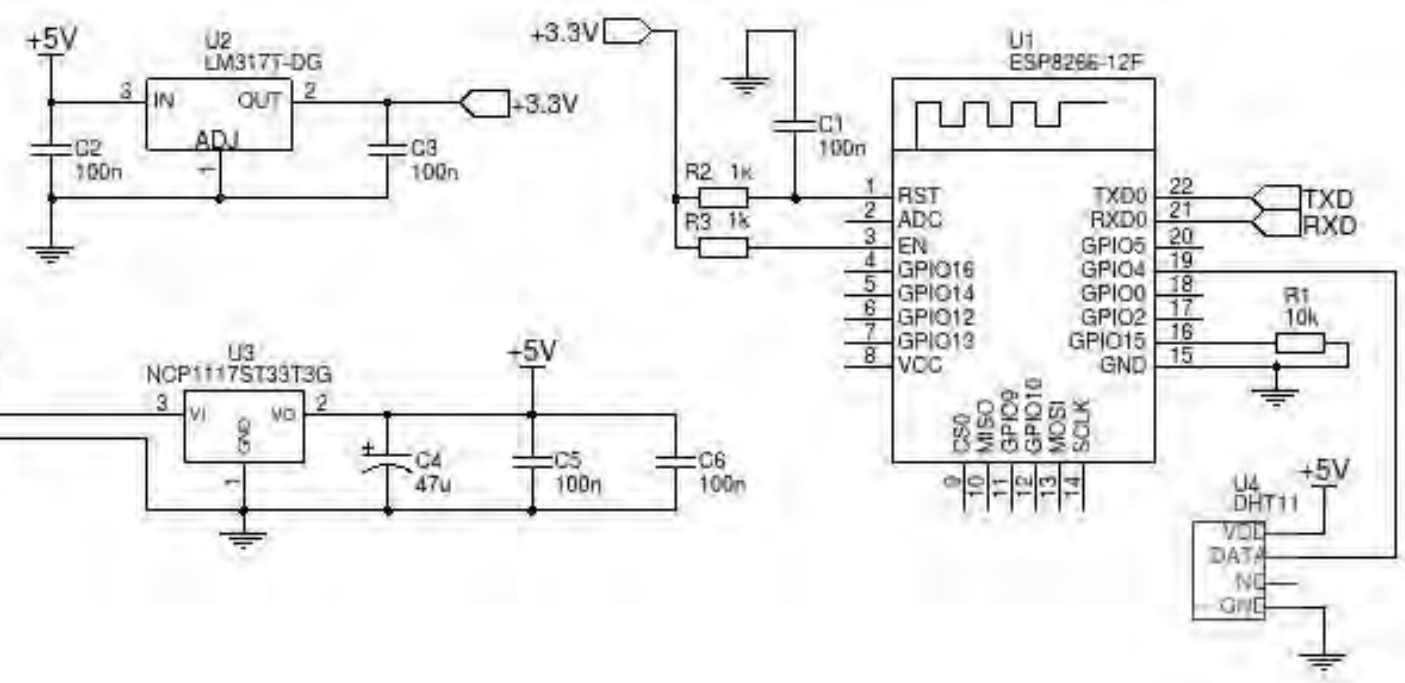

Рис. 7. Апаратна реалізаџія сенсорного вузла бездротової МСВВ

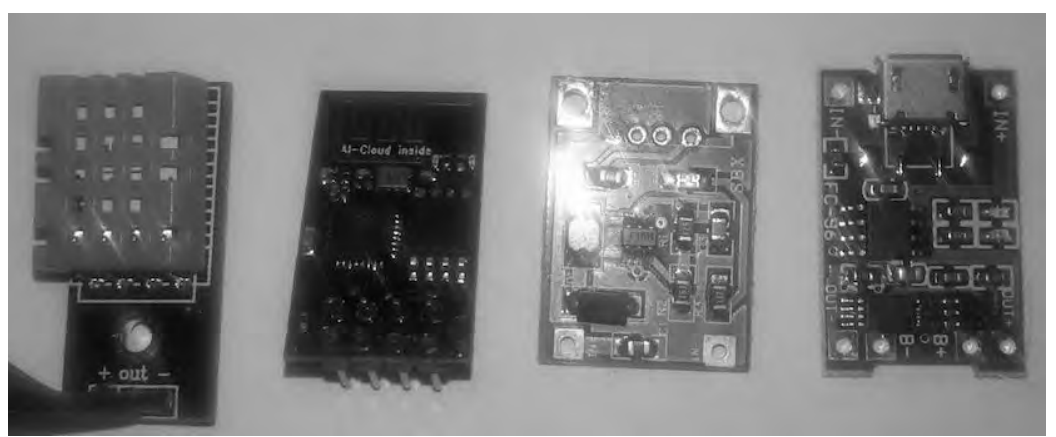

Рис. 8. Комплектуючі прототипу сенсорного вузла бездротової МСВВ

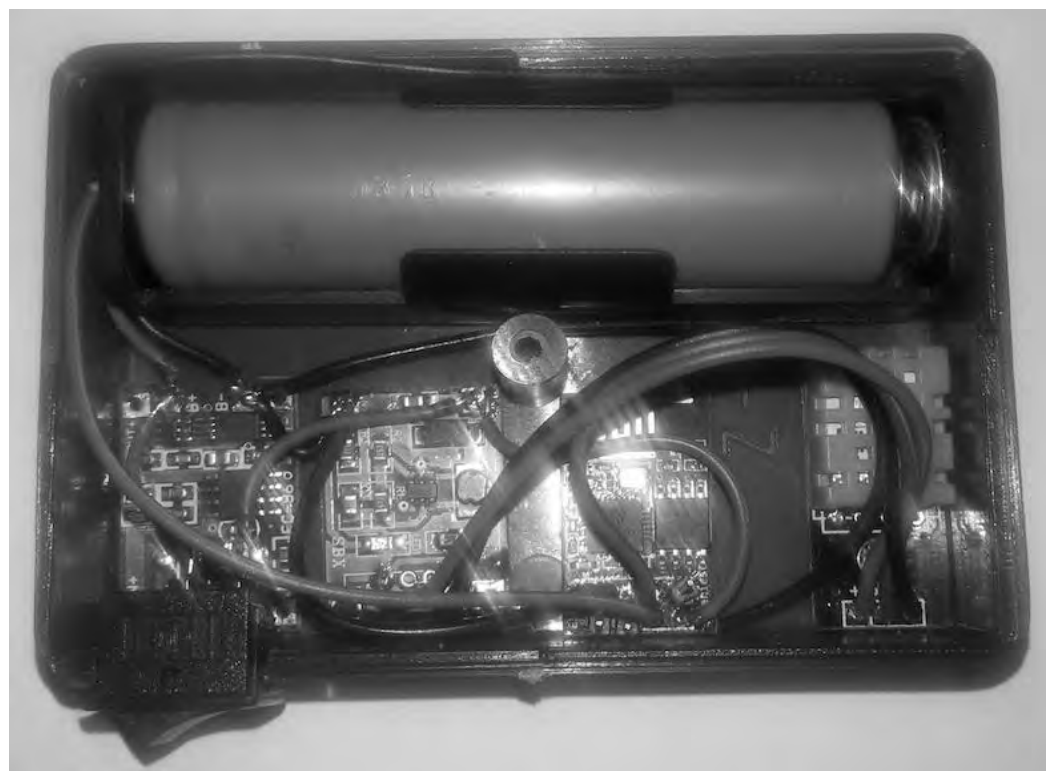

Рис. 9. Конструкиія прототипу сенсорного вузла бездротової МСВВ

Конструкція прототипу виконавчого вузла складається 3 трьох комплектуючих (рис. 11) та корпуса 3 габаритними розмірами $90 \times 65 \times 35$ мм (рис. 11), в якому зроблено отвори для роз'ємів Arduino Uno та силових контактів реле. Основні характеристики реалізованого прототипу виконавчого вузла такі: 1) максимальна кількість пристроїв під управлінням одного вузла - 11 шт.; 
2) максимальна потужність виконавчого пристрою - 2 кВт; 3) споживана потужність виконавчого вузла $-1,25$ Вт; 4) габаритні розміри $-90 \times 65 \times 35$ мм.
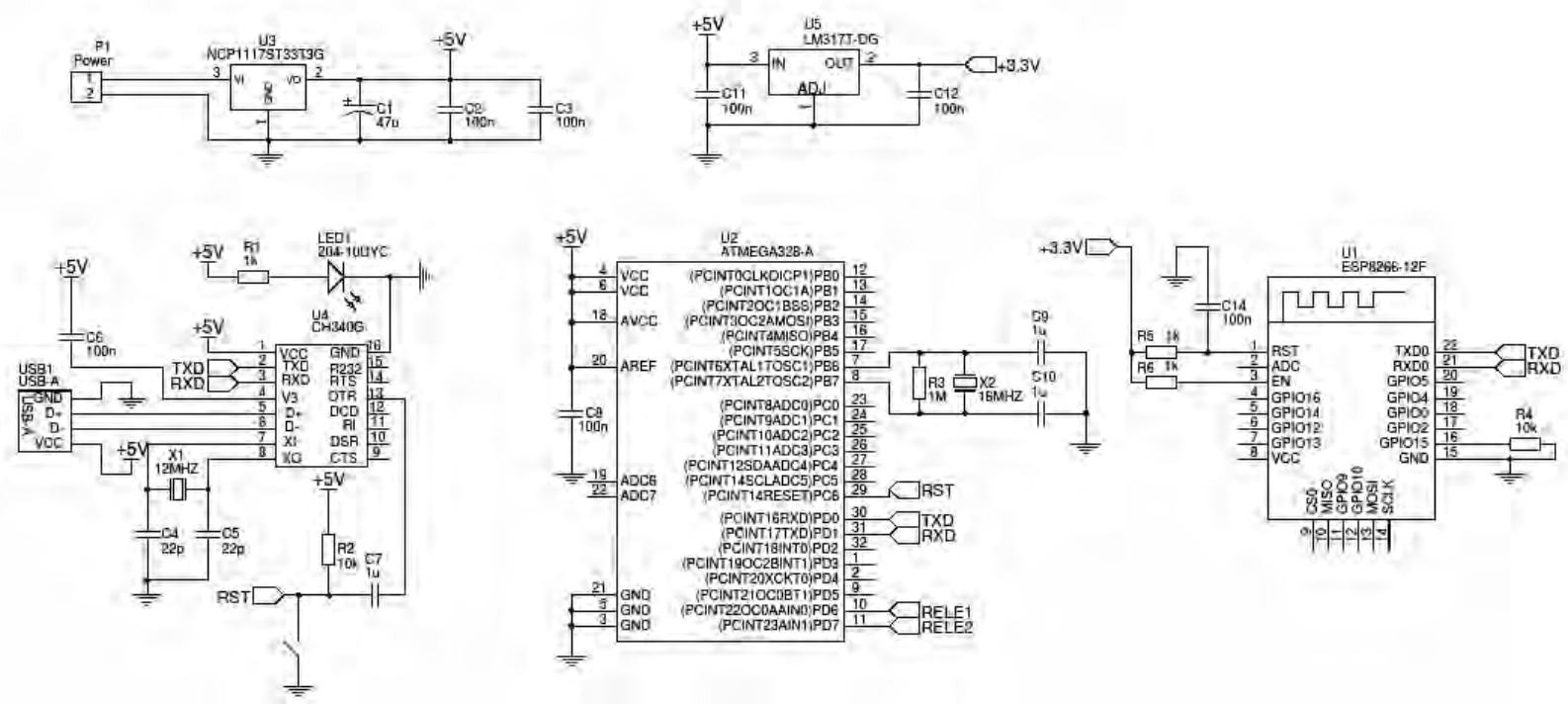

Рис. 10. Апаратна реалізаиія виконавчого вузла бездротової МСВВ

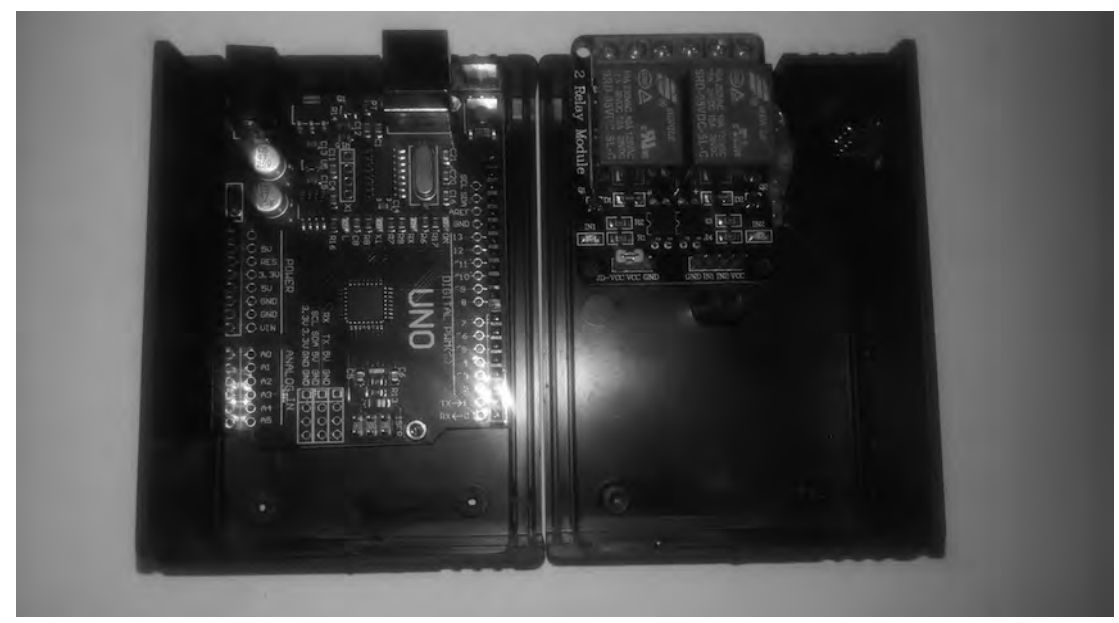

Рис. 11. Конструкиія прототипу виконавчого вузла бездротової МСВВ

\section{Висновки}

У роботі розглянуто проблему розроблення бездротової мережі сенсорних та виконавчих вузлів у складі кіберфізичної системи, проаналізовано різні варіанти компонування вузлів бездротової МСBВ, різні варіанти технологій бездротового зв'язку для ііі побудови та способи реалізації схеми бездротового зв'язку. Запропоновано структуру та алгоритми роботи бездротової MCBB на основі технології бездротового зв'язку Wi-Fi, наведено результати реалізації сенсорних та виконавчих вузлів мережі. Базова функціональність розробленої МСВВ забезпечує: 1) можливість збирання вимірювальної інформації $з$ давачів фізичних величин та виконання команд виконавчими пристроями в автономному режимі; 2) можливість віддаленого перегляду показів давачів та введення команд для виконавчих пристроїв 3 консолей управління. 
Наукові результати, подані у цій статті, отримано під час виконання дослідницького проекту ДБ/КІБЕР (реєстраційний номер 0115U000446), 01.01.2015-31.12.2017, за фінансової підтримки Міністерства освіти і науки України.

1. Melnyk A.,Cyber-physical systems: problems of creation and directions of development, Transactions on Computer systems and networks, Lviv Polytechnic National University Press, No. 806, 2014. - P. 154-161 (in Ukrainian). 2. Melnyk A. Integration of the levels of the cyber-physical system, Transactions on Computer systems and networks, Lviv Polytechnic National University Press, No. 830, 2015. - P. 61-67 (in Ukrainian). 3. Golembo V., Botchkaryov A. Approaches to the construction of conceptual models of cyber-physical systems, Transactions on Computer Science and Information Technology, Lviv Polytechnic National University Press, No. 864, 2017. - P. 168-178 (in Ukrainian). 4. Rajeev Alur, Principles of Cyber-Physical Systems, The MIT Press, 2015. - 464 p. 5. Siddhartha Kumar Khaitan and James D. McCalley, Design Techniques and Applications of CyberPhysical Systems: A Survey, IEEE Systems Journal, Volume: 9, Issue: 2, June 2015. - P. 350-365. 6. Boyko Yu. M., Lokazyuk V. M., Mishan V. V. Conceptual characteristics of the implementation of wireless sensor networks, Transactions of Khmelnytsky National University, No. 2, 2010. - P. 94-97 (in Ukrainian). 7. Botchkaryov A., Golembo V. Applying intelligent technologies of data collection to autonomous cyberphysical systems, Transactions on Computer systems and networks, Lviv Polytechnic National University Press, No. 830, 2015. - P. 7-11 (in Ukrainian). 8. Melnyk A., Golembo V., Botchkaryov A. The new principles of designing configurable smart sensor networks based on intelligent agents, Transactions on Computer systems and networks, Lviv Polytechnic National University Press, No. 492, 2003. - P. 100-107 (in Ukrainian). 9. Botchkaryov A. Collective behavior of mobile intelligent agents solving the autonomous distributed exploration task, Transactions on Computer systems and networks, Lviv Polytechnic National University Press, No. 546, 2005. - P. 12-17 (in Ukrainian). 10. Botchkaryov A. Structural adaptation of the autonomous distributed sensing and computing systems, Transactions on Computer systems and networks, Lviv Polytechnic National University Press, No. 688, 2010. - P. 16-22 (in Ukrainian). 11. Botchkaryov A. The problem of organizing adaptive sensing and computing processes in autonomous distributed systems / Transactions on Computer systems and networks, Lviv Polytechnic National University Press, No. 745, 2012. - P. 20-26 (in Ukrainian). 